\title{
A Copa do Mundo ao cair da Tarde: a cobertura jornalística da conquista da seleção alemã
}

\author{
The World Cup in A Tarde: the press \\ coverage of the victory of the German team
}

João Batista de Abreu Junior | Universidade Federal Fluminense Professor Doutor do Programa de Pós-Graduação em Mídia e Cotidiano E-mail: joaobajr@uol.com.br

Roberto Falcão | Universidade Federal Fluminense Mestrando do Programa de Pós-Graduação em Mídia e Cotidiano E-mail: roberto.falcao@terra.com.br

\begin{abstract}
Resumo
O trabalho analisa, por meio da cobertura do diário $A$ Tarde, de Salvador, a convivência entre a delegação alemã de futebol e a população local de Santa Cruz Cabrália, no sul da Bahia, que serviu de base para a seleção que conquistou a Copa do Mundo de futebol em 2014. A partir dos critérios de identidade cultural, globalização e seleção jornalística, mostra que a estratégia de aproximação com os moradores marcou a cobertura de $A$ Tarde e criou um clima simpático à seleção alemã.
\end{abstract}

Palavras-Chave: futebol, Copa do Mundo, seleção alemã, Santa Cruz Cabrália, identidade

\begin{abstract}
This article aims to analyse the social interaction between the German football delegation and the local people of Santa Cruz Cabralia, city of the state of Bahia where the 2014 world champion team was based during the Fifa World Cup Brazil 2014, through the coverage made by the brazilian diary newspaper A Tarde, from Salvador. From the criteria of cultural identity, globalization, and news editing, this paper shows how the German strategy to build social connections with the local inhabitants influenced the coverage of A Tarde and created a good atmosphere in favor of the German team.
\end{abstract}

Keywords: football, Word Cup, German team, Santa Cruz Cabrália, identity 
Este artigo examina as ediçóes dos cadernos especiais de Copa do Mundo do jornal $A$ Tarde, da Bahia, no período entre 12 de junho de 2014, data do jogo de abertura da competiçãa ${ }^{1}$, e 14 de julho, dia seguinte à partida final ${ }^{2}$. São examinadas 33 ediçóes e daí extraídas as matérias que refletem a pauta local inserida no universo global da cobertura.

A seleçáo da Alemanha escolheu como sede a cidade de Santa Cruz Cabrália, tradicional localidade turística no litoral sul da Bahia. Desta forma, $A$ Tarde pôde refletir em sua cobertura a interação de jogadores e demais membros da delegação alemã com a população local. A caminhada da Alemanha na competição serve como fio condutor para o entendimento deste relacionamento entre delegação e população e sua percepção pelos jornalistas de $A$ Tarde. $\mathrm{O}$ curioso é que outra seleção europeia, a da Suíça, também se baseou na Bahia, mas não conquistou a mesma atenção de $A$ Tarde.

Os critérios de relevância adotados na análise dos textos referem-se especificamente a esta pesquisa, sem guardar relação direta com os graus de interesse de um fato noticioso na ótica dos jornalistas de $A$ Tarde, embora muitas vezes possam até se confundir. As matérias analisadas, em seu processo de apuração e edição, foram avaliadas como merecedoras de publicaçáo pelos produtores de conteúdo dos jornais (repórter, editor etc.).

Para valerem publicação, os jornalistas envolvidos na produção e edição do diário analisado avaliaram que as matérias apresentaram elementos que, combinados, lhes atribuíram um valor noticioso, ou valor-notícia. Segundo Mauro Wolf (2008), é possível "definir os valores-notícia (news value) como um componente da noticiabilidade".

Eles representam a resposta à seguinte pergunta: quais acontecimentos são considerados suficientemente interessantes, significativos, relevantes, para serem transformados em notícia? (...) Na seleção dos eventos a serem transformados em notícias, os critérios de relevância funcionam conjuntamente, em "maços": são diversas as relações e as combinaçóes que se determinam entre diferentes valores/noticia para "recomendar" a seleção de um fato. (WOLF, 2008, p. 202)

Nilson Lage (2001, p. 92) explica que a construção de um texto guarda relação direta com a importância ou o interesse de seu fato gerador.

No campo das avaliaçóes empíricas, alguns itens são consideráveis: a proximidade, $a$ atualidade, a identificação, $a$ intensidade, $o$ ineditismo, a oportunidade. $\mathrm{Na}$ realidade das empresas de comunicação, esses fatores influem segundo a ordem de interesses de classe ou grupo dominante; secundariamente, operam ainda gostos individuais de pessoas que dispóem momentaneamente de algum poder, ou estratégias fundadas em avaliaçóes prévias quanto a efeitos, conseqüências ou desdobramentos de um fato noticiado. (LAGE, 2001, p. 93 - 94; grifo do autor)

Lage explica que, em relação à proximidade, "o raciocínio corrente é o de que o homem se interessa principalmente pelo que lhe está próximo”. Mas ele observa que a proximidade é em si relativa, pois pode ser próximo aquilo que guarda relação comercial, mas não necessariamente está perto geograficamente. 
Desta forma, a distante China torna-se próxima do Brasil em função do grande número de jogadores brasileiros que jogam naquele país literalmente do outro lado da Terra ${ }^{3}$.

Em outra direção, Lage também indica que as trocas culturais se encaixam neste critério de proximidade. E é justamente devido a esta ótica cultural que as matérias jornalísticas que constituem o objeto desta pesquisa podem ser agrupadas. De todos os critérios de noticiabilidade, o de proximidade é comum a todos os textos considerados locais. O conceito de proximidade é determinado pelo repertório cultural e pelo lugar em comum com os leitores ${ }^{4}$.

\section{Alemanha em Cabrália}

A discussão da identidade à luz do mundo globalizado é fundamental para a compreensão de como as categorias global e local se apresentam mutuamente. Stuart Hall (2001, p. 12) aponta uma mudança em curso na pós-modernidade, em que "o sujeito, previamente vivido como tendo uma identidade unificada e estável, está se tornando fragmentado; composto não de uma única, mas de várias identidades, algumas vezes contraditórias ou não-resolvidas”.

A partir da constituição das modernas nações, Hall adverte que as culturas nacionais se formam a partir de personagens com origens diferentes, em classe, gênero ou etnia, mas que buscam uma identidade a que todos possam pertencer. Observando que a globalização é inerente à humanidade desde a era moderna, ele compreende que este fenômeno ganha maior dimensão na pós-modernidade.

O que é importante para nosso argumento quanto ao impacto da globalização sobre a identidade é que o tempo e o espaço são também as coordenadas básicas de todos os sistemas de representação. Todo meio de representação - escrita, pintura, desenho, fotografia, simbolização através da arte ou dos sistemas de telecomunicação - deve traduzir seu objeto em dimensóes espaciais e temporais. Assim, a narrativa traduz os eventos numa seqüencia temporal "começo-meio-fim"; os sistemas visuais de representação traduzem objetos tridimensionais em duas dimensöes. Diferentes épocas culturais têm diferentes formas de combinar essas coordenadas espaço-tempo. (HALL, 2001, p. 70; grifo do autor)

No mundo de 2014, ainda mais globalizado graças à internet, as imagens atravessam os continentes em um intervalo próximo do tempo real. Cada indivíduo é potencialmente produtor e emissor de conteúdo. No entanto, a mídia tradicional, pelo seu alcance, ainda exerce papel fundamental na difusão de valores. E assim se fez em Cabrália, com a mídia jogando papel fundamental no registro da aliança entre as identidades alemã e brasileira. $\mathrm{O}$ jornal $A$ Tarde, por exemplo, registrou todos os movimentos neste sentido, captando os elementos da identidade brasileira valorizados pela delegação alemã.

Esta identidade brasileira, segundo José Carlos Reis, pode ser buscada em Gilberto Freyre, com a valorização da miscigenação, ainda hoje percebida como um atributo nacional que se traduz pela expressão "democracia racial". Em Casa Grande \& Senzala (1933), a ressignificação feita por Freyre da relação 
entre o português dominador e seus dominados - o indígena e principalmente o negro - desemboca em uma naçáo caracterizada fortemente pela mediação, pela negociação entre diferentes.

A formação brasileira tem sido um processo de equilíbrios e antagonismos. A mediação africana aproximou os extremos, brancos e índios, que sem ela dificilmente teriam se entendido bem. As culturas europeia e ameríndia eram estranhas e antagônicas. A sociedade brasileira é uma das mais democráticas, flexíveis e plásticas. Ela conseguiu equilibrar harmoniosamente antagonismos dificilmente superáveis: culturas europeia e africana e indígena, economia agrária e pastoril, fazendeiro e jesuíta, bandeirante e senhor de engenho. E equilibrou o antagonismo maior: senhor e escravo. (REIS, 2003, p. 78)

A seleção da Alemanha escolheu justamente para se concentrar a terra onde surgiu o Brasil europeizado (e daí depois a sua identidade). Os integrantes da delegação procuraram conhecê-la para nela se misturar, e assim se tornarem "estranhos próximos". E experimentaram a realidade local, notadamente no que se refere à música e sua expressão corporal, a dança, com uma experiência intensa, semelhante à de alguém que realiza "turismo cultural", como observa Muniz Sodré6:

Pelos relatos que tivemos, os alemães adotaram uma comunidade, eles se aproximaram de elementos da cultura brasileira e da baiana. Poderíamos dizer que eles se comportaram à maneira de quem faz um 'turismo cultural', alguém que não se limita a passear e consumir, mas participa da cultura local. Não quer apenas ver, comprar, se divertir, mas também participar comunitariamente por alguns dias. É como se houvesse a compressão do tempo, e uma vivência de 10 ou 15 dias às vezes é mais rica que uma outra de um ano inteiro. (SODRÉ, 2015, entrevista ao autor)

A música revela-se muito cara à identidade baiana. Não por acaso a professora Agnes Mariano buscou nas letras das melodias os elementos para construir a identidade baiana em $A$ invenção da baianidade. No prefácio, o professor Albino Rubim estende à "Boa Terra" as características anteriormente percebidas por Freyre para todo o Brasil: "[A] baianidade é um projeto coletivo, uma utopia que deseja cordialidade, comunhão e democracia racial" (in MARIANO, 2009, p.14). Mariano amplia esta consideração com maior detalhamento:

(...) o espírito de conciliação pode se expressar na defesa da cordialidade, permitindo a convivência entre opostos, da comunhão, isto é, o compartilhamento entre iguais e diferentes, dos direitos, deveres e experiências e da fusão de elementos distintos gerando algo novo, uma opção transformadora - o sincretismo, a miscigenação, a antropofagia". (MARIANO, 2009, p. 207; grifos da autora)

De volta a Freyre: em 1947, quase 70 anos antes da passagem da seleção alemã pela Bahia, ele relativiza futebol, música e Bahia no prefácio à primeira edição de $O$ negro no futebol brasileiro, obra clássica de Mario Filho. Freyre enumera como características da autenticidade do futebol brasileiro "um pouco de samba, um pouco de molecagem baiana e até um pouco de capoeiragem pernambucana ou malandragem carioca" e recorre a uma imagem para expressar isso, a da "dança dançada baianamente por um Leônidas". (in MARIO FILHO, 2003, p. 25) 
No campo do futebol, Mario Filho seguiu a perspectiva sociológica de Freyre, atribuindo à participação do negro, e da mestiçagem por ele provocada, a identidade do futebol brasileiro, conforme Soares:

A visão de Mário Filho, como a de outros intelectuais, artistas e escritores de sua época, está condicionada pela crença em um Brasil que, em poucos anos, teria passado da escravidão para a integração da raça, via mestiçagem, caldeamento, amálgama ou conciliação. (SOARES, 2000, p. 115)

Helal e Soares (2002) registram que, a partir dos anos 1930, o futebol faz parte do projeto de construçáo de uma identidade nacional, e Mario Filho é autor significativo deste movimento. Também questionam se, no início do século XXI, a globalização não contribuiria para desintegrar esta mesma identidade nacional (por extensão, é possível atribuir o mesmo raciocínio para identidades de outras naçóes). Os autores, no entanto, advertem que isso não se dá sem processos de diálogos e resistência, e constroem um raciocínio específico para a Copa do Mundo (aqui entendida como a competição em si, não especificamente uma de suas ediçóes).

Mesmo diante desse processo de fragmentação das identidades nacionais, da formação de outras formas de identificação híbridas, dos processos de resistência $e$ de reforço das identidades locais, a Copa do Mundo ainda traz uma estrutura narrativa que representa os nacionalismos afirmados entre os séculos XIX e XX. (HELAL e SOARES, 2002, p. 4).

Apontar onde a identidade brasileira (ou baiana) sofreu interferência da delegação alemã em Cabrália é a que se propóe a análise das matérias publicadas em $A$ Tarde. Para este estudo, foram consideradas e classificadas exclusivamente as matérias de caráter noticioso publicadas no Caderno de Esportes especial do jornal, veiculado durante a Copa do Mundo. Não foram consideradas colunas de opiniáo, como as assinadas diariamente por Tostáo e Veríssimo, e outras cujos autores se revezaram durante o período da competição. Excepcionalmente examinou-se a coluna Copa e Cozinha, assinada por Raul Moreira - que mescla notas opinativas com outras informativas, mas aqui consideradas somente as de valor noticioso.

De 12 de junho - na abertura da Copa do Mundo - a 14 de julho, dia seguinte à partida final, foram analisadas 33 ediçóes. As matérias que tratavam diretamente da Alemanha somaram 113, média de 3,42 matérias / edição. Não foram consideradas matérias que apenas citavam a Alemanha, sem lhe atribuir algum tipo de protagonismo.

A proposta é estabelecer uma linha do tempo, de maneira a acompanhar a Alemanha (e sua relação com a população baiana, particularmente a da cidade de Santa Cruz Cabrália e o distrito Santo André, onde ficou concentrada a delegação).

No dia 12 de junho, data do jogo oficial de abertura da Copa (Brasil 3 x 1 Croácia), matéria em tom de feature ${ }^{8}$ relata a véspera do time alemão e a "estreia" de sua campanha, uma brincadeira contra o time da Escola Boa Esperança, de Santa Cruz Cabrália, que venceu por 2 a 0. O relato descontraído descreve o 
momento relaxado de uma das equipes favoritas ao título da Copa do Mundo e aponta o encontro com o mundo lúdico das crianças, destacando como uma das características dos alemães a docilidade, comumente associada ao leque de atribuições dos baianos: “(...) os alemães foram dóceis com os meninos, incentivando-os a cada jogada (...)”. Mais adiante, o texto destaca que “(...) foi mais uma oportunidade para os alemães darem seu agora já conhecido show de carisma. A quantidade de autógrafos, gestos de carinhos e autógrafos foi incontável”.

No dia 17 de junho, o jornal $A$ Tarde comemorou juntamente com a população de Cabrália a estreia da Alemanha com goleada de 4 a 0 sobre Portugal. Em relato publicado no alto de página de página ímpar ${ }^{9}$ (p. 7), com fotos da população nativa torcendo para a Alemanha. A identificação com a seleção visitante fica explícita ainda no parágrafo de abertura do texto, na declaração de um "novo torcedor" da Alemanha, colhida pela reportagem no intervalo da partida, quando o jogo já estava 3 a 0.

Paulo Cesar Leandro, de frente a sua TV, não conseguia parar de berrar, sorrir e pular. (...) ainda no intervalo da partida, ele saiu de carro e com bandeiras pelas ruas do distrito de Santo André. Buzinando e gritando, informava: Estamos dando 3 a 0. É3 a 0, meu irmão." (A Tarde, edição de 17.06.2014, Caderno Especial Copa 2014, p.7).

Mas nem só grandes alegrias viveram os alemães, e seus torcedores preferenciais de Cabrália. No dia 23 de junho, o relato da volta da equipe à concentração em Santo André, após empate frustrante com Gana em 2 a 2, em Fortaleza, também demonstra os sentimentos da população local por náo poder desfrutar da companhia dos astros. O que causa estranhamento na reportagem, e isso está enfatizado no texto, é o afastamento deliberado dos jogadores, sem interação com a populaçáo local, o que até entáo não fora verificado no material publicado pelo jornal. O tom do texto é de decepção com os jogadores alemães:

Ontem (...) foi tudo diferente. Eles simplesmente se recolheram em seus aposentos para frustração das dezenas de nativos e turistas que (...) esperaram na praia por uma chance de tirar as fotos com os astros. A espera até o anoitecer foi em vão. Nenhum jogador apareceu. (A Tarde, edição de 23.06.2014, Caderno Especial Copa 2014, p.7).

No entanto, a decepção dá lugar ao espírito de entusiasmo logo na edição do dia seguinte, 24 de junho, em que alemães e suíços são incluídos em uma mesma matéria sobre a saída da Bahia das duas delegaçóes para disputar jogos fora do estado. O clima de "intimidade” é visível nas declaraçóes dos habitantes locais, que se tomam por próximos às estrelas internacionais. Ian Calebe e Teresa Rajáo são dois destes personagens que aparecem na matéria, e também são deles as fotos que ilustram o material, todas tornando literalmente visível a interação entre astros do futebol e população local, sobretudo graças a um espaço de convivência tipicamente brasileiro (e baiano), a praia, sempre referida como democrática e aglutinadora. A praia é o espaço de quatro das cinco fotos publicadas, em situaçôes envolvendo o suíço Inler (foto 1) e os alemães Mertesacker (2), Schürrle (3), Götze (4) e Joachim Low (5), conforme pode-se conferir na figura 1, em seguida: 
Figura 1

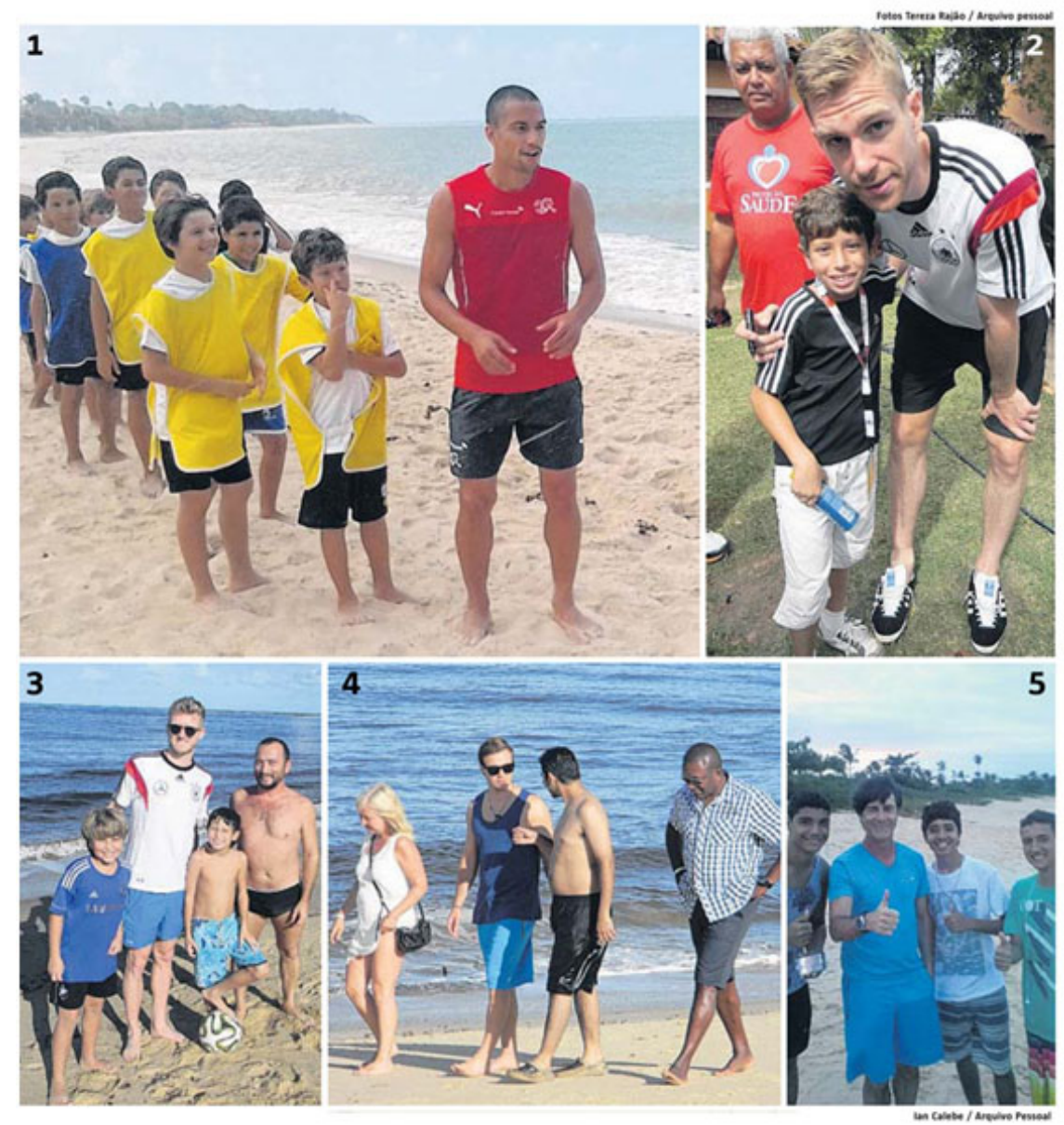

A Tarde, edição de 24.06.2014, Caderno Especial Copa 2014, p.8

\section{Do confronto contra o Brasil até a final}

A vitória sobre a França no Rio de Janeiro credenciou a Alemanha a enfrentar o Brasil numa das semifinais, no dia 8. A Tarde publica cinco matérias consideradas relevantes. A mais significativa retrata a confusão sentimental (e identitária) por que passam os habitantes de Cabrália, forçados a optar entre a pátria Brasil e a visitante cordial Alemanha por eles adotada (e vice-versa). A questão fica clara logo na abertura da matéria intitulada "Alemães conquistam as crianças e dividem os coraçôes de Cabrália”:

Patriotismo versus gratidão. A semifinal da Copa opôs dois fortes sentimentos em Santa Cruz Cabrália. A pequena cidade baiana de 25 mil habitantes, destoando de todo o restante deste Brasil de 200 milhóes, estará dividida no jogo de hoje. Cabrália é a base da Alemanha na Copa. Seleção que a cidade abraçou durante o evento. E por ela, vale dizer, também foi abraçada. (...) o coração da cidade foi rachado em dois. (A Tarde, edição de 08.07.2014, Caderno Especial Copa 2014, p.8; grifo do texto).

A relação afetiva entre moradores de Cabrália e os alemães simboliza a imagem de visitantes identificados com os hábitos e costumes da terra, seja da "Terra Brasil" ou da "Boa Terra da Bahia". E a música, claro, faz parte deste repertório 
de apropriaçóes, como fica claro em duas notas publicadas na página 7 da mesma edição. Intitulada "Sorria, você está na Bahia, versão alemã", uma delas trata de um videoclipe com cenas dos alemães no Brasil (particularmente na Bahia, mais ainda em Cabrália) ao som da música $A$ luz de Tieta, de Caetano Veloso:

Os alemães já são os campeóes de simpatia na Copa do Mundo. A conexão com a
cultura brasileira está presente em cada lance protagonizado pelos craques, personagens
de um vídeo divulgado no site oficial oficial da Federaçâo Alemã ${ }^{10}$ e que tem como tema
a música Tieta ${ }^{11}$. Sempre sorridentes e atenciosos, os germânicos aparecem treinando,
ou em momentos de brincadeiras, além de distribuirem autógrafos para todos os lados.
(A Tarde, edição de 08.07.2014, Caderno Especial Copa 2014, p.7).

$\mathrm{Na}$ trilha da música baiana e intitulada "Lepo Lepo contra a Seleção Brasileira?”, outra nota aborda a possível comemoração de gols da Alemanha ao som do sucesso de carnaval:

A canção baiana Lepo Lepo pode se voltar contra o Brasil. A Seleção da Alemanha, que treina no Sul da Bahia, diz que vai fazer a coreografia da música na comemoração de gols hoje. Agora, é esperar para ver. Ou melhor, para não ver!!! (A Tarde, edição de 08.07.2014, Caderno Especial Copa 2014, p.7).

Os textos de $A$ Tarde refletem a associação que se costuma fazer entre Seleção Brasileira de futebol e o Brasil como nação. Daí não torcer pela equipe nacional pode parecer um ato antipatriótico. Mas esta relação é em grande parte fruto da construção de identidade nacional que começa nos anos 1930, e que é muito bem percebida por Mario Filho, em nota à 2a edição de $O$ negro no futebol brasileiro, de 1964.

Pouca gente se dá conta do que se exige de um jogador de futebol. Ele tem de representar um clube, uma cidade, um Estado, a Pátria. O que se espera dele é que encarne as melhores virtudes do homem, no caso do brasileiro, as melhores virtudes do homem brasileiro. (MARIO FILHO, 2003, p.16).

Irmão de Mario Filho, o cronista Nelson Rodrigues contribuiu para consolidar esta fusão (e confusão) entre nação, patriotismo, esporte e seleção nos textos que publicava na imprensa: "a seleção é a pátria em calçôes e chuteiras"12, escreveu em um texto para o jornal $O$ Globo e publicado originalmente em 26 de maio de $1976{ }^{13}$.

$\mathrm{Na}$ edição de $A$ Tarde de 9 de julho, dia seguinte à goleada de 7 a 1 da Alemanha sobre o Brasil, a maior parte do material publicado tratava do jogo e, principalmente, do placar incomum. No entanto, um texto publicado com destaque no alto da página traçou o histórico de uma seleção que se fez popular. Em ordem cronológica, relata os muitos momentos de interação dos alemães com a população de Cabrália: vídeo cantando o hino do Bahia com a camisa do clube, visita de índios pataxós à concentração, baba ${ }^{14}$ com as crianças em escola municipal, aula para aprender a dançar o Lepo Lepo, videoclipe ao som de $A$ luz de Tieta.

O texto, em tom de comentário e assinado pelo editor-coordenador de Esportes Marcelo Machado, termina com um elogio rasgado à estratégia de aproximação dos alemães com os locais de Cabrália: "Esta Alemanha pode até 
deixar escapar o tetra no domingo (o que não acredito), mas já é um sucesso a ser seguido como modelo de futebol e de comunicação. Nota 10!”

Na edição de 10 de julho, dois dias após a vitória sobre o Brasil, a edição de $A$ Tarde traz matéria sobre a festa alemã na volta a Cabrália, ainda na madrugada do dia 9. Mas o relato não traz testemunhos dos jogadores; é produzido a partir de depoimentos de terceiros, já que os integrantes da delegação permaneceram no hotel durante o dia, recuperando-se do desgaste da semifinal.

Em 11 de julho, $A$ Tarde publica o material de maior destaque a respeito da Alemanha em Cabrália, pois a delegação permaneceria somente até este dia na cidade. Uma chamada enorme na capa do caderno dá o tom de despedida: "Auf Wiedersehen", que significa adeus.

O repórter Ricardo Palmeira, também autor das fotos dos moradores que a ilustram, conta como a rotina de Cabrália sofreu forte impacto com a presença dos astros alemães. Em outra matéria, abaixo da principal, os integrantes da delegação alemã elogiam a cidade e seus habitantes, conforme resume o auxiliar técnico Hans Flick: “(...) Além de ser um lugar paradisíaco, é, ao contrário das grandes cidades, um excelente lugar para termos sossego, estarmos mais juntos e nos encontrar mais facilmente com as pessoas que nos fazem bem. Somos privilegiados em termos tido esta experiência. Foi brilhante."

Aqui pode-se perceber como a delegação alemã explorou a dicotomia segundo a qual Cabrália representaria o Brasil romântico do homem afável, em contraste com o Brasil das grandes cidades, marcadas pela impessoalidade. Com sua declaração, Flick demonstra como a interpretação do filósofo Jean-Jacques Rousseau, do século XVIII, de um Mundo Novo selvagem mas hospitaleiro, habitado por nativos gentis, ainda permanece no imaginário europeu apesar de quase três séculos passados desde a publicação da obra do pensador suíço. José Sávio Leopoldi relata que Rousseau tornou-se conhecido como o "filósofo do bom selvagem" por conferir ao "estado de natureza" características positivas.

Rousseau (..) atribui àquele estado características positivas a ponto de ser chamado o
filósofo do bom selvagem, em alusão às qualidades superiores que, a seu ver, exibiam
os individuos que viviam no estado de natureza. Uma de suas características básicas
é, para Rousseau, o ambiente natural extremamente abundante e acolhedor, a ponto
de parecer ter sido criado na medida exata para servir ao homem (...) (LEOPOLDI,
2002, p. 159)

Na edição do dia 12, o relato do último treino da Alemanha, na véspera, informa que os jogadores receberam as "energias" de 20 índios da tribo Pataxó residentes em Coroa Vermelha, a sete quilômetros de Cabrália. A foto que ilustra a matéria mostra índios em trajes típicos cercados por fotógrafos e cinegrafistas. O cacique Zeca Pataxó, chefe político e porta-voz da tribo, explica que seu povo estaria torcendo pela Alemanha na final contra a Argentina e trabalhando efetivamente pela vitória: "Hoje (ontem), viemos fazer nossa dança de celebração que envia energias positivas e pede sucesso aos jogadores. (...) vamos fazer nossos rituais de preces para pedir a vitória da Alemanha.” 
No dia 13, A Tarde exibe várias matérias de apresentação da final contra a Argentina. Dois textos opinativos destacam a interação alemã com a Bahia: um assinado por um convidado, o músico Manno Góes, tratando da música como elemento de aproximação; e o segundo, de autoria do repórter Ricardo Palmeira, reafirmando o casamento da eficiência dentro de campo com a simpatia fora dele.

A edição do dia 14 fecha a cobertura da passagem pela Bahia da seleção alemã, campeã na véspera. Em destaque, o texto publica a declaração do atacante Thomas Müller, de que voltaria a Cabrália dentro de 20 anos para recordar e novamente comemorar. O que chama a atenção não são as expressões utilizadas nos elementos textuais de atração à leitura, como título, antetítulo e olho ${ }^{15}$ (ver figura 2).

A culinária é valorizada no título "Tetra mundial da Alemanha leva tempero baiano". A hospitalidade é o mote do antetítulo "BOA TERRA - Jogadores destacam Cabrália como parte importante da grande conquista”. E a ideia de experiência única, só possível na Bahia, é destacada no olho com declaração de Müller: "O que vivemos na Bahia foi inesquecível. Daqui a 20 anos, pretendo reunir com todos os jogadores e voltarmos a Cabrália para reviver tudo”.

Todos os textos analisados, aqueles considerados de grande relevância, realçam qualidades demonstrados pelos alemães como simpatia, humildade e carinho. O comportamento dos habitantes de Cabrália - e isso se reflete nas matérias - passa a impressão de que os locais deixam-se afetar pelos alemães, que, mais desenvolvidos social e economicamente, desejam aproximar-se da populaçáo local, desprovida de recursos. Algo como um encontro entre centro (alemães) e periferia (locais) ${ }^{16}$ , em uma troca em que todos oferecem e recebem, afetando-se mutuamente.

Figura 2

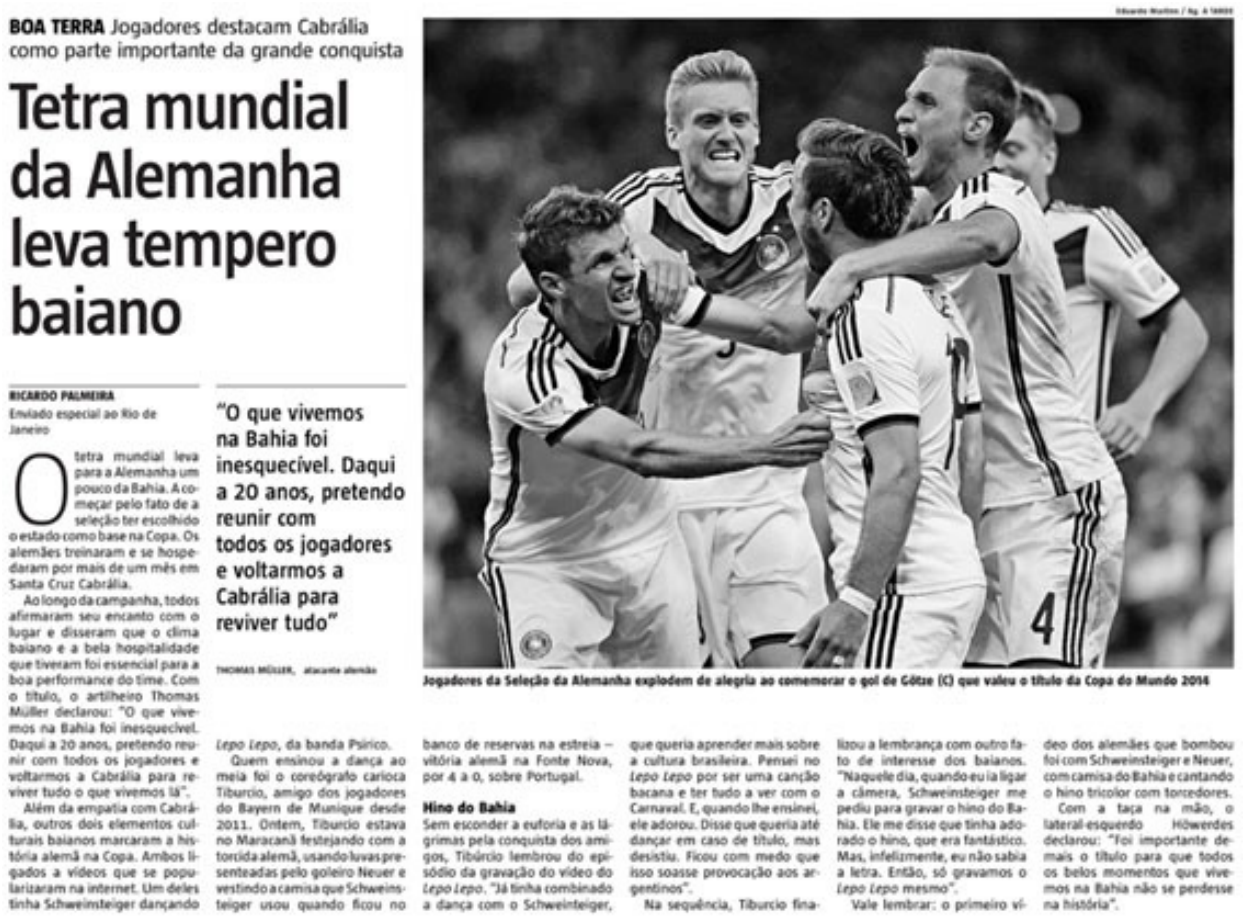

A Tarde, edição de 14.07.2014, Caderno Especial Copa 2014, p.7 


\section{Cordialidade alemã}

A passagem da Alemanha pela Bahia permite perceber como a vivência de uma experiência local pode ser importante na busca pelo resultado em esporte de alto rendimento, contrariando o comportamento usual de reclusão em concentrações. Os jogadores e integrantes da comissão técnica da Alemanha experimentaram, por sua opção, alguns dos elementos formadores da identidade brasileira, como a música e a dança, E ainda foram reconhecidos pela amabilidade, cordialidade e boa convivência, valores tradicionalmente associados ao brasileiro e particularmente ao baiano.

O repórter Ricardo Palmeira, que acompanhou a seleção alemã em Cabrália e na final no Maracanã, relata que os alemães adotaram a Bahia e buscaram entender hábitos e costumes, ou seja, sua identidade. Ele cita um episódio por ocasião do sorteio dos grupos, realizado na Costa do Sauípe, em dezembro de 2014, envolvendo o técnico Joachim Low e o diretor Oliver Bierhoff, como indicador da preparação dos alemães para a temporada em Cabrália.

A Alemanha caiu no grupo E, com estreia justamente na Bahia, na Fonte Nova. E ai eu tinha de falar com alguém da Alemanha. Um bolo de repórteres brigava para entrevistar o Low e o Bierhoff. E aí eu falei em inglês com o assessor de imprensa da Alemanha, disse que era de um jornal da Bahia. E ele me perguntou: 'Correio?' Eu disse que não, mas não cheguei a falar para onde trabalhava pois ele me interrompeu: 'A Tarde?'. Eu disse que sim e que precisava fazer somente uma pergunta ao Bierhoff. Ele me falou então: 'Uma não, duas'. Chamou o Bierhoff à parte para eu falar com ele. ${ }^{17}$ (FREIRE, 2015, entrevista ao autor)

Não é possível perceber pelas matérias de $A$ Tarde quanto de planejamento e quanto de espontâneo teve a interação da Alemanha com a populaçáo local, mas a análise dos textos deixa claro que os moradores locais receberam positivamente as açôes daqueles que viriam a ser os campeóes mundiais.

A Copa do Mundo de futebol, assim como outros megaeventos esportivos, remete à questão da identidade nacional. Evidencia-se a possibilidade de estabelecer as diferenças entre as nações, criando interesse por jogos desprovidos de atração esportiva. $\mathrm{Na}$ a Copa do Mundo de 1998, quando se enfrentaram Estados Unidos e Irâ, a imprensa internacional destacou, mais do que a rivalidade no futebol, a hostilidade entre os dois países e o choque de identidades culturais.

Renato Ortiz (2012, p.7) destaca a importância da definição da identidade "em relação a algo que lhe é exterior, ela é uma diferença”. A identidade possuiria uma dimensão interna e, por isso, não seria suficiente explicitar somente a diferença. Torna-se necessário perceber a sua formaçáo a partir dos diferentes pontos de identificação. 
Em Cultura brasileira e identidade nacional, Ortiz traça uma história crítica da percepção da identidade nacional e destaca como um momento importante para a afirmação da nação a postulação de um Brasil mestiço, trazida por Freyre nos anos 1930. Embora Ortiz considere rica a discussão posterior a Freyre, é possível perceber ainda hoje uma herança do conceito de mestiçagem no discurso da identidade brasileira. Vale observar que Freyre trabalha como pilar a mestiçagem do ponto de vista étnico, mas também a reveste de uma perspectiva cultural.

A questão da identidade nacional mostra-se fundamental para entender como o futebol brasileiro participa de sua construção. Paralelamente, o esporte tem sua própria identidade moldada a partir da identidade nacional. Conforme observa Luiz Carlos Ribeiro (2012), o próprio Freyre reflete a respeito da importância do futebol na formaçáo da cultura brasileira, em um texto clássico publicado originalmente em 17 de junho de 1938, na sua coluna no Diário de Pernambuco sob o título "Football mulato".

Acaba de se definir de maneira inconfundivel um estilo brasileiro de futebol, e esse estilo é uma expressão a mais do nosso mulatismo ágil em assimilar, dominar, amolecer em dança, curvas ou em músicas, as técnicas europeias ou norte-americanas mais angulosas para o nosso gosto: sejam elas de jogo ou de arquitetura. Porque é um mulatismo o nosso - psicologicamente, ser brasileiro é ser mulato - inimigo do formalismo apolíneo sendo dionisiaco $^{18}$ a seu jeito - o grande feito mulato. (FREYRE, 1938, p. apud RIBEIRO, 2012, p. 357)

A coluna de Freyre de 1938 apresenta viés otimista, motivada pela vitória do Brasil sobre a Thecoslováquia, por 2 a $1^{19}$, o que garantiu a passagem da seleção à fase semifinal da Copa da França. À época, o mundo já era universalmente conectado, muito embora não se pudesse imaginar as velocidades de comunicação e transporte que hoje caracterizam o fenômeno da globalização, como observa Stuart Hall (2001):

Que impacto tem a última fase da globalização sobre as identidades nacionais? Uma de suas características principais é a "compressão espaço-tempo", a aceleração dos processos globais, de forma que se sente que o mundo é menor e as distâncias mais curtas, que os eventos em determinado lugar têm um impacto imediato sobre pessoas e lugares situados a uma grande distância. (HALL, 2001, p. 69)

Um dos destes eventos a que Hall se refere é a Copa do Mundo. No entanto, até mesmo um megaevento como este guarda espaço para textos jornalísticos de natureza local, que acentuam a peculiaridade do lugar do jogo, das características da plateia, do clima e, dependendo do enfoque, até mesmo de certo exotismo presente na narrativa. Afinal, a prática do futebol moderno - que tem como berço a Inglaterra do final do século XIX - atravessou o Atlântico, depois o Pacífico, ganhou popularidade, assumiu sua mestiçagem e transformou-se em um negócio de alta lucratividade, concretizando assim a análise de David Harvey (1992), para quem a flexibilidade do capital provoca a compressão tempo-espaço e ajuda a reduzir fronteiras espaciais em nome de um mercado mundializado. 
A rapidez do tempo aniquila o espaço, colocando territórios momentaneamente em contato através das tecnologias de comunicação, em tempo real. Esta aparente simultaneidade de espaços acarreta consequências sociais e culturais, além de modificaçóes do sentimento em relação ao mundo, às coisas em geral.

Neste jogo coletivo em que a competitividade do negócio predomina muitas vezes sobre a disputa do esporte em si, resta saber quem sai ganhando.

\section{Referências bibliográficas}

ASSOCIAÇÃO NACIONAL DE JORNAIS. Jornais centenários. Disponível em <http://www.anj.org.br/jornais-centenarios-2/>. Acesso em 8 fev. 2016.

paulista compra grupo A Tarde. Disponível em < http://www.anj.org. br/2016/01/29/empresa-paulista-compra-grupo-a-tarde/>. Acesso em 8 fev. 2016.

ATARDETV. Internauta flagra jogadores da Alemanha cantando hino do Bahia. Disponível em <https://www.youtube.com/watch?v=IiKxU-g_CJY>. Acesso em 21 nov. 2015

DEUTSCHER FUSSBALL-BUND. Kinderträume 2014: DFB unterstützt Projekte in Brasilien. Disponível em <http://tv.dfb.de/video/ kindertraeume-2014-dfb-unterstuetzt-projekte-in-brasilien/9764/ $\quad \rightarrow$. Acesso em 21 nov. 2015

FILHO, Mario Rodrigues. O negro no futebol brasileiro. Rio de Janeiro: Mauad, 2003.

FOLHA DE S.PAULO. Jornal 'A Tarde”, da Bahia, é vendido para empresa paulista. Disponível em < http://wwwl.folha.uol.com.br/ mercado/2016/01/1734706-jornal-a-tarde-da-bahia-e-vendido-para-empresa-paulista.shtml>. Acesso em 20 fev. 2016.

GOVERNO DO ESTADO DA BAHIA. Dx Group instala novas empresas na Bahia. Disponível em <http://www.sde.ba.gov.br/Noticia. aspx?n=34074>. Acesso em 20 fev. 2016.

HALL, Stuart. A identidade cultural na pós-modernidade. Rio de Janeiro: DP\&A, 2001.

HARVEY, David. Condição Pós-Moderna: uma pesquisa sobre as origens da mudança cultural, São Paulo, Loyola, 1992

HELAL, Ronaldo; SOARES, Antonio Jorge. O declinio da pátria de chuteiras: futebol e identidade nacional na Copa do Mundo de 2002. In: REUNIĀO ANUAL DA ASSOCIAÇÃO NACIONAL DE PROGRAMAS DE PÓS-GRADUAÇÃO EM COMUNICAÇÃO, 12. Anais. Recife, 2003. 
JORNAL DO SENADO. Senador celebra os 27 anos do Diário do Amazonas. Disponível em <http://www12.senado.gov.br/jornal/edicoes/2012/03/16/senador-celebra-os-27-anos-do-diario-do-amazonas $>$. Acesso em 8 fev. 2016.

LAGE, Nilson. Ideologia e técnica da notícia. Florianópolis: Insular, 2001. LEOPOLDI, José Savio. Rousseau - estado de natureza, o "bom selvagem" $e$ as sociedades indigenas. Revista Alceu. v. 2, n. 4, p. 158 a 172, 2002. MARIANO, Agnes. A invenção da baianidade. São Paulo: Annablume, 2009

O GLOBO. China já tem 25 brasileiros na lista e os dois últimos técnicos da seleção. Disponível em < http://blogs.oglobo.globo.com/planeta-que-rola/post/china-ja-tem-25-brasileiros-na-liga-e-os-dois-ultimos-tecnicos-da-selecao.html>. Acesso em 27 fev. 2016

ORTIZ, Renato. Cultura brasileira e identidade nacional. São Paulo: Brasiliense, 2012.

PALMEIRA, Ricardo. Depoimento [05 dez 2015]. Entrevistador: Roberto Falcão

REIS, José Carlos. As identidades do Brasil: de Varnhagen a FHC. Rio de Janeiro: FGV, 2003.

RODRIGUES, Nelson. "Narciso às avessas." In: A pátria de chuteiras. Rio de Janeiro: Nova Fronteira, 2013.

SOARES, Antonio Jorge. "História e a invenção de tradições no futebol brasileiro." In: A invenção do país do futebol. Ronaldo Helal, Antonio Jorge Soares, Hugo Lovisolo. Rio de Janeiro: Mauad, 2001.

SODRÉ, Muniz. Depoimento [03 dez 2015]. Entrevistador: Roberto Falcão WOLF, Mauro. Teorias das comunicações de massa. São Paulo: Martins Fontes, 2008.

\section{Notas}

1. Brasil 3 x 1 Croácia, em São Paulo.

2. Alemanha 1 x 0 Argentina, no Rio de Janeiro.

3. Levantamentos feitos pela imprensa no início de janeiro de 2016 contabilizavam 25 jogadores brasileiros em times chineses, mas o número foi alterado desde entâo. Pelo menos um jogador voltou ao Brasil, o atacante Robinho.

4. Neste estudo, foram analisadas as matérias classificadas como de grande relevância, como se verá no decorrer deste capítulo.

5. A expressão aqui utilizada no sentido de vivência de outra cultura, não no sentido normalmente atribuído a ela pelo mercado, de viagens para consumo de chamada alta cultura (visita a museus, casas de espetáculo etc.).

6. Em depoimento de Muniz Sodré, em 3 de dezembro de 2015.

7. Leônidas da Silva, jogador dos anos 1930 e 1940, na verdade é carioca. 
8. Feature, no linguajar jornalístico, refere-se a uma matéria normalmente atemporal, a respeito de uma curiosidade e náo de um fato tido como de importância.

9. As páginas ímpares dos jornais são consideradas mais nobres, pois atraem mais a atenção do que as páginas pares com as quais formam dupla. Assim, a página 7 é mais nobre que a página 6 , por exemplo. Esta lógica se reflete nas tabelas de anúncios, nas quais o espaço nas páginas ímpares normalmente custa mais caro que nas páginas pares.

10. Apesar de o vídeo ter sido retirado posteriormente do site da Federaçáo Alemã de Futebol por um problema de direitos autorais, ele ainda se encontrava disponível para visualização no Youtube em 2 de dezembro de 2015, disponibilizado por um terceiro. Por respeito à legislaçáo, não está apontado na bibliografia deste artigo o endereço eletrônico.

11. No texto do jornal, o nome da música foi simplificado para a forma usual com que o público costuma se referir a ela.

12. Expressão retirada de crônica originalmente publicada no jornal O Globo, em 26 de maio de 1976 e republicada em coletânea de 2013 pela Editora Nova Fronteira intitulada A pátria de chuteiras. A obra ganha como título a forma como a expressão ficou mais conhecida.

13. A expressão está em coletânea de crônicas publicada pela Editoria Nova Fronteira, em 2013, e inspirou o título da obra (A pátria de chuteiras). Para referência, consultar bibliografia deste estudo.

14. Baba é termo popular para designar jogo de futebol não oficial, normalmente disputado por amigos, conhecido em outras regióes do país como "pelada" ou "racha".

15. Olho, no jargão jornalístico, é um texto curto, normalmente reprodução de uma declaração, retirado do corpo da matéria para ganhar destaque.

16. Para o conceito de "centro e periferia", utilizado majoritariamente em estudos econômicos, ver Desenvolvimento e a Cepal: da industrializaçáo por substituição de importaçôes à transformação produtiva com equidade.

17. Em depoimento de Ricardo Palmeira ao autor em 5 de dezembro de 2015.

18. Freyre repete aqui uma prática comum no pensamento ocidental de tomar os deuses gregos Apolo e Dionísio como referências de comportamentos antagônicos. Para Freyre, Apolo significa a aplicação, enquanto Dionísio está relacionado à criatividade, característica que é atribuída ao brasileiro.

19. Jogo-desempate realizado em Bordeaux, em 14 de junho de 1938, devido a um empate em 1 a 1 na primeira partida entre os dois países pelas quartas-de-finais, na mesma cidade. 